\title{
Systemic aspects of securing the health safety of the elderly
}

\author{
MATEUSZ PAPLICKI ${ }^{1, A, B, D-F}$, ROBERT SUSŁO ${ }^{2, A, B, D-F}$, \\ KAROL DOPIERAŁA ${ }^{1, B, D}$, JAROSŁAW DROBNIK $2, A, D$
}

\author{
${ }^{1}$ Developmental Age Traumatology and Emergency Medicine Unit, General Medicine Department, Wrocław \\ Medical University, Poland \\ ${ }^{2}$ Gerontology Unit, Public Health Department, Health Sciences Faculty, Wrocław Medical University, Poland
}

A - Study Design, B - Data Collection, C - Statistical Analysis, D - Data Interpretation, E - Manuscript Preparation, F - Literature Search, G - Funds Collection

Summary The rapid aging of Polish society brings increasing stress to bear on both informal and formal support systems. The article aims at discussing the scope of care-related challenges in ageing societies and both current and future status of systemic remedies in Poland. Formal support systems, including social and medical care, are underdeveloped, understaffed, underfinanced, desynchronized, and generally unready to confront the increasing demands of the increasing number of elderly people, who typically suffer from multiple chronic and degenerative diseases that require holistic geriatric care. Such care can only be delivered by teams of specialists that include a physician specializing in geriatrics, a nurse, a physiotherapist, a psychologist, and a social worker. Although demanding and seemingly expensive, this kind of approach actually cuts costs, as it not only improves health outcomes, but also prolongs the duration of functional independency of the elderly, allowing them to function in their home environment, delaying institutionalization, and lessening the pressure on long-term care facilities. As the resources of the formal support systems charged by Polish law with providing health safety to the elderly are scarce, the main burden of care rests, and will continue to rest, on informal caregivers - predominantly family members. Given the deficits of both physicians and of institutions specializing in geriatric care, primary care physicians and their offices are forced to fill the gap, especially for the comparably fit elderly people dwelling in the community. Consequently, family care physicians should include activities to expand their geriatric competences into their continuous professional development schedules. Key words: primary health care, geriatrics, health care reform, aged, patient safety.

Paplicki M, Susło R, Dopierała K, DrobnikJ. Systemic aspects of securing the health safety of the elderly. Fam Med Prim Care Rev 2018; 20(3): 267-270, doi: https://doi.org/10.5114/fmpcr.2018.78272.

\section{Demands of care for the elderly}

The aging of society, and especially the increase in the numbers of the "old old" (those 75-84 years old) and of the "oldest old" (85 and older), puts increasing strain on both the formal and informal systems of support, including social and medical care, support, and treatment. At the same time, the modern way of life with the increasing geographical mobility of people and the increasing popularity of the nuclear family over multigenerational families (resulting in significant numbers of widowed people living alone in their late adulthood) limits the availability of the informal care traditionally provided within households [1]. This makes it crucial to develop long-term care (LTC) services aiming at providing the elderly with holistic services, health, and support, both stationary and ambulatory, without time limitations and with the aim of improving functional independence and delaying institutionalization [2]. The article aims at defining the scope of care-related challenges created by ageing of societies and discussing the current and future status of systemic remedies in Poland, including limited access to specialized geriatric care and the resulting key role of primary care physicians in securing the health needs of the elderly.

The demand for assistance services in daily living depends not only on the extent of a person's functional limitations, but also on surrounding conditions [3], and especially on the social and formal environment [4]. In England, the deterioration of the activities of daily living proved to be the strongest determinant of the need for formal support. The main reason for men receiving informal support is a decline in physical health, while a decline in mental health is the more common reason for women to receive it [5]. The existence and progression of disabilities that limit activities of daily living are known predictors of institutionalization, but not all elderly people wish to be admitted to care institutions, meaning that they continue to dwell in the community [3] and often fail to utilize the institutional and even home care services that remain available [6]. The hidden gap between the met and unmet needs for assistance services can only be estimated crudely, but the deficit is typically twice as large in people who live alone as in those who live together with others. This translates into a difference in the number of hours of help received per week as high as 16 hours, resulting in serious adverse health effects, including increased numbers of cases of emaciation and dehydration, burns and falls $[7,8]$. Because of psychomotoric and mental limitations, the elderly, especially when left without adequate support, are prone to accidents, especially traffic accidents [9], and are at increased risk of suffering from various kinds of crimes [10], often resulting in serious health disturbances or even death [11]; these can be difficult to differentiate from age-related and disease-related deaths [12]. Because of their limited mobility and generalized helplessness, even emergency room utilization may be lower in case of elderly who live alone [13]. Apart from living alone, other factors increasing the risk of needs being left unmet include multiple daily deficiencies in living activities and low income [14]. Even now, in societies that are not yet very aged, making up for the shortage in the number of hours of help required by all the partly or fully dependent elderly people would require enormous financial assets and workforces, which are not available and will not become available in the foreseeable future [7]. 
Care for the elderly is both demanding and expensive, as it requires a multidimensional approach and the coordination of multiple services delivered by various providers. In a patient who needs geriatric care, old age translates into complicated set of deficiencies in physical and mental functions, resulting in multiple organ insufficiency - the so-called frailty syndrome - which typically coexists with several chronic diseases, requiring fine-tuned therapy using many drugs [15]. Even from medicolegal point of view, care for the elderly often becomes formally complex, especially in cases patients become incapable of effectively expressing themselves [16], which may affect their giving or refusing consent to medical diagnostics and treatment, and cooperation of medical personnel with their legal guardians is needed [17].

Interdisciplinary geriatric care needs to be holistic, encompassing all the medical, physical, mental, and social problems of the patient. It thus needs to involve of a team of specialists including at least a physician specialized in geriatrics, a nurse, a physiotherapist, a psychologist, and a social worker [18]. Multiple standardized scales need to be used and periodically reused to objectively evaluate the patient's status and its subsequent changes [2]. The most widely used instruments for assessing functional deficiencies are the Barthel scale, the Activities of Daily Living scale (ADLs) scale, and the Instrumental Activities of Daily Living scale (IADLs) [19]. A common platform of medical information exchange and future action planning and coordination allows the use of assets to be optimized both for the patient and the health care system, allowing the main demands of geriatric care to be followed: equal access for all elderly people to geriatric services; high availability of geriatric services; continuous and time-unlimited nature of geriatric care; high quality of geriatric care; and holistic care provided by specialized geriatric teams [2]. Paradoxically, this complex approach not only increases the quality of care, but also saves costs, as it limits the expense of otherwise uncoordinated, repeated multiple specialist consultations and recurring hospitalizations, as well as the complications resulting from low patient compliance, polypharmacy, and iatrogenic complications [20]. The benefits of the complex geriatric care approach include lower risk of death (by $22 \%$ ) during one year's observation; $47 \%$ lower likelihood of institutionalization; $12 \%$ fewer hospitalizations; and indicators of patients' independent functioning in their native environment being improved by $72 \%$ [2]. The geriatric approach can be effectively supported by modern medical technologies that address the health needs of community-dwelling elderly people [21]; they are not only effective means of health promotion and disease prevention, but also provide a multitude of solutions maximizing various aspects of health safety in old age, including remote supervision, emergency assistance, care, diagnostics, and treatment [22].

\section{Geriatric care in Poland}

Responsibility in Poland for ensuring protection of human life and at least a basic level of health safety lies with the state [23] acting directly through its organs or indirectly through local governments, nongovernmental organizations (NGO), and the private sector [24]; these duties also extend to the elderly and their specific health needs [25]. The aging of Polish society is progressing very rapidly thanks to increasing average lifespans and the decreasing number of children being born to the average women of reproductive age. Together these will decrease the Polish population if no opposing processes, such as immigration, occur. In the 1950 s, merely $4 \%$ of people were aged 65 years or older was, while this is expected to reach $15 \%$ in the 2020s, and $30 \%$ in the 2050s [26]. In 1950, the number of Polish citizens who were 80 years or older was 522,000 while in the year 2013 these numbered 1,483,000. As early as 2009, 25\% of all patients admitted to Polish hospitals were 65 years old or older, and the cost of their treatment consumed $33 \%$ of hospital budgets; at the same time, the cost of hospitalization for people aged 65 years and over was nearly double the average for all age groups; the cost of hospitalization of people 80 years and older was nearly three times greater than the average for all age groups. It is expected that, in the next decade, the proportion of elderly people in Polish hospital patients will reach $50 \%$. As more than $40 \%$ of Polish elderly people suffer from healthrelated limitations in at least in one of the basic everyday activities [27], it must be stressed that, despite various formal and institutional forms of support, the main burden of care on the elderly in Poland rests on informal caregivers, who are in most cases family members [2].

Institutional care for the elderly is underdeveloped [28], and the financial assets assigned to social and medical care have been scarce and inadequately distributed for many decades [29]. The expected increase in demand for these services will add additional strain to the country's budget [30]. This problem is especially vivid for patients suffering from chronic debilitating health conditions that require constant supervision, care, or nursing, such as dementia, which is more common among the elderly than in younger people [31]. Health promotion and disease prevention have for many decades been invariably low-priority items in the distribution of financial assets, and the elderly in Poland thus suffer from potentially preventable illnesses. Vaccinations are one of the saddest examples of the failure of disease prevention, as even those required by law are being successfully avoided by an increasing proportion of the Polish population [32]. The low uptake of recommended vaccinations, including influenza vaccine, prevents the elderly from benefitting from the phenomenon of hoard immunity, which results from limitations in the spread of communicable diseases among populations with a sufficiently high proportion of people who are immune. Additionally, the elderly are rarely vaccinated themselves, although the benefits are unquestionable [33].

The main health problems among the elderly are multiple chronic and degenerative diseases, especially diseases of civilization; the current average duration of life in good health is well below 65 years of age, being 58.1 years for men and 62.1 years for women. This leaves a significant section of the Polish population not only unfit to work with full efficiency until retirement age (currently 65 for males and 60 for females). Moreover, for health related reasons, the elderly also become increasingly dependent on others' help during the last 15 years of life [34], as the average life expectancy is currently 72 years for men and 77 years for women. In Poland, around $40 \%$ of elderly people die at home and about $50 \%$ in hospitals. It is important to stress that the need for assistance and help does not increase linearly with age; instead, there is a steep rise during the last year leading to death, which in Poland is provided for the most part by informal caregivers, predominantly family members, who support the elderly in everyday living tasks, which most often include shopping, cooking, personal hygiene, getting dressed and undressed [26]. The Vulnerable Elders Survey, VES-13, allows identification of elderly patients who are at risk of suffering from a sudden drop in general health status or dying because of age-related causes within the next two years. It is estimated that around $25 \%$ of the elderly in Poland are at such a risk. Such patients should undergo the holistic geriatric evaluation (Całościowa Ocena Geriatryczna; COG), which is in fact only part-financed by the Polish national health insurance fund (Narodowy Fundusz Zdrowia; NFZ). As the funding covers only PLN 150 (EUR 35), which is several times smaller than the actual cost of this procedure. Because of serious underfunding, complex geriatric care is available to less than $1 \%$ of elderly people in Poland, evening though its introduction would save around 1400-1700 PLN (329-400 EUR) per patient per year over standard medical care [2]. Generally, the greater the risk of sudden deterioration of the health status of the patient, the greater the patient's benefits from access to complex geriatric care [18]. Currently, 
the average Polish geriatric patient is 81 years old and has received five medical diagnoses, of which the most common are hypertension, depression, urinary incontinence, falls, dementia, diabetes, chronic heart insufficiency, gastric ulcers, emaciation, delirium, iatrogenic syndromes, chronic renal insufficiency, and neoplastic diseases. These require, on average, the concurrent use of at least seven drugs [2]. This complex pharmacotherapy is often poorly coordinated, which is associated with a high risk of iatrogenic complications, as the average elderly person in Poland is consulted and treated by multiple physicians specializing in every medical discipline except geriatrics: $76 \%$ of all treated older patients are treated, in order of decreasing frequency, by specialists in internal diseases, general surgery, cardiology, ophthalmology, orthopedics and motor system traumatology, neurology, urology, and rheumatology. In the year 2012, 77\% of the patients in geriatric wards in Poland were being treated because of three main diagnoses: Alzheimer's disease; extrapyramidal and movement disorders; and other degenerative diseases of nervous system, not elsewhere classified (ICD-10 classes $\mathrm{G} 30, \mathrm{G} 20-\mathrm{G} 26$, and $\mathrm{G} 31$ respectively) [20].

Although in Poland responsibility for LTC tasks is divided between medical care and social care, with a significant participation from NGOs and the private sector, a significant proportion of the dependent elderly receive either no support or support inadequate to their needs; access to this care is difficult, limited by highly formalized and bureaucratic entry procedures. The coordination of actions of medical care and social care is difficult, and their efficacy is limited, as they are independent of each other in all important aspects: legal, formal, organizational, and financial. There is a gap in support services, including transitional care (providing patients who are leaving acute care facilities for transfer home or to LTC facilities with short stays at specialized wards or facilities specializing in treatment and rehabilitation) and respite care (allowing for time-limited relief care to prevent burn-out in informal caregivers [2] and possibly also limiting the scale of domestic violence against isolated elderly people, which is still underestimated, as even $75 \%$ of victims do not report it [35]).

The medical services delivered to elderly people by different kinds of providers - including hospitals, LTC facilities, outpatient and ambulatory specialist medical consultation offices, emergency medical care, and primary medical care - all need syn- chronization, especially as the role of family medicine as a medical specialty and its intended place in the Polish healthcare system needs further defining in the context of the demands of the aging society [36]. The exacerbating problems of social and health care in aging society call for urgent action, but even drastic financial and organizational changes will not solve the problem, given the limited availability of care and medical staff in the short term [37]. As the number of people 80 years and older is expected to rapidly rise in Polish population - reaching about $10 \%$ of the general population and around $25 \%$ of the population of the elderly by the year 2050 - it is clear that more geriatric and palliative care specialists are needed, as there are currently only around 300 physicians specializing in geriatrics in Poland, who practice mostly in urban areas. The actual demand for geriatric physicians is from 2.5 [2] to as much as 5 times higher [27]; the number of beds in specialized geriatric hospital wards is ten times less than the recommendation of the World Health Organization, given the size of the Polish population; the number of specialized geriatric ambulatory facilities should thus be increased by a factor of five [2]. Many Polish physicians specialized in geriatrics are not currently working as geriatricians on account of the lack of geriatric medical facilities that could employ them [18]. The training programs for the other medical staff who take care of the increasing number of patients in the 65-79 age group need ongoing adjustments to meet the emerging problems; this especially concerns physicians who take care of elderly patients on an everyday basis, such as those working in emergency medicine, internal medicine and, especially, family medicine specialists [38], who are practically "first-line geriatricians". It is estimated that currently each primary care physician practicing in Poland takes care of an average of 250 elderly patients [2]. The complex nature of geriatric care demands from primary care physicians rising levels of organization and management competences, including learning how to apply new coordination tools, like process mapping [39].

\section{Guidelines for primary care physicians}

Primary care physicians in Poland should take into the consideration the current demographic trends and include geriatric competences into their future continuous professional development schedules.

Source of funding: This work was funded by the authors' resources. Conflict of interest: The authors declare no conflict of interests.

\section{References}

1. Vlachantoni A, Shaw R, Willis R, et al. Measuring unmet need for social care amongst older people. Popul Trends 2011; 145: 56-72, doi: https://doi.org/10.1057/pt.2011.17.

2. Bień B. Opieka zdrowotna nad osobami starszymi w Polsce - geriatria dzisiaj i jutro. Kontrola Państwowa 2016; 1 specjalny: 30-51. Available from URL: https://www.nik.gov.pl/plik/id,10370.pdf (in Polish).

3. Davin B, Paraponaris A, Verger P. Demographic and socioeconomic factors associated with needs for home assistance among community-dwelling elderly: a study from the French Home Survey Handicaps-Disabilities-Dependence. Rev Epidemiol Sante Publique 2005; 53(5): 509-524.

4. Solé-Auró A, Crimmins E. Who cares? A comparison of informal and formal care provision in Spain, England and the USA. Ageing Soc 2014; 34(3): 495-517, doi: https://doi.org/10.1017/S0144686X12001134.

5. Vlachantoni A, Shaw R, Evandrou M, et al. The determinants of receiving social care in later life in England. Ageing Soc 2015; 35(2): 32-45, doi: https://doi.org/10.1017/S0144686X1300072X.

6. Walter-Ginzburg A, Guralnik J, Blumstein T, et al. Assistance with personal care activities among the old-old in Israel: a national epidemiological study. J Am Geriatr Soc 2001; 49(9): 1176-1184.

7. LaPlante $\mathrm{M}$, Kaye $\mathrm{H}$, Kang $\mathrm{T}$, et al. Unmet need for personal assistance services: estimating the shortfall in hours of help and adverse consequences. J Gerontol B Psychol Sci Soc Sci 2004; 59(2): 98-108.

8. Kamińska M, Brodowski J, Karakiewicz B. The influence of socio-demographic and environmental factors on the fall rate in geriatric patients in primary health care. Fam Med Prim Care Rev 2017; 19(2): 139-143, doi: https://doi.org/10.5114/fmpcr.2017.67869 (in Polish).

9. Susło R, Siuta J, Trnka J, et al. Osoby w podeszłym wieku jako szczególni uczestnicy ruchu drogowego. Acta Univ Lodz Folia Oecon 2013; 297: 171-182 (in Polish).

10. Gęsicki M, Trnka J, Susło R, et al. Ludzie starsi jako ofiary przestępstw przeciwko życiu i zdrowiu. Acta Univ Lodz Folia Oecon 2013; 297: 149-158 (in Polish). 
11. Trnka J, Szatny H, Susło R. Gwałtowne przyczyny zgonów ludzi w starszym wieku. In: Kowalski J, Szukalski P, eds. Nasze starzejqce się społeczeństwo: nadzieje i zagrożenia. Łódź: Wydawnictwo Uniwersytetu Łódzkiego; 2004: 203-209 (in Polish).

12. Susło R, Siuta J, Trnka J, et al. Sądowo-lekarskie problemy przy określaniu przyczyny zgonu w przypadku osób starszych, które zmarły w niejasnych okolicznościach. Acta Univ Lodz Folia Oecon 2013; 297: 225-236 (in Polish).

13. Walter-Ginzburg A, Chetrit A, Medina C, et al. Physician visits, emergency room utilization, and overnight hospitalization in the old-old in Israel: the cross-sectional and longitudinal aging study (CALAS). J Am Geriatr Soc 2001; 49(5): 549-556.

14. Desai $\mathrm{M}$, Lentzner $\mathrm{H}$, Weeks J. Unmet need for personal assistance with activities of daily living among older adults. Gerontologist 2001; 41(1): 82-88.

15. Wróblewska I, Susło R, Wróblewska Z, et al. Zespół kruchości - częsty problem obniżajq̨cy jakość życia osób w podeszłym wieku. In: Jakubaszko J, ed. Postępy medycyny ratunkowej 2018. Wrocław: Polskie Towarzystwo Medycyny Ratunkowej, SR-Poligrafia; 2018: 73-84 (in Polish).

16. Trnka J, Drobnik J, Susło R. The role of primary care physicians in enabling validation of a patient's ability to make legal statements and express a last will. Fam Med Prim Care Rev 2017; 19(3): 319-322, doi: http://doi.org/10.5114/fmpcr.2017.69298.

17. Drobnik J, Trnka J, Susło R. Ambushes related to collecting patients' consent for medical procedures by family doctors. Fam Med Prim Care Rev 2017; 19(3): 298-302, doi: http://doi.org/10.5114/fmpcr.2017.69294.

18. Wieczorowska-Tobis K. Najlepsze wzorce opieki nad osobami w wieku podeszłym - polityka geriatryczna w wybranych krajach. Kontrola Państwowa 2016; 1 specjalny: 86-96. Available from URL: https://www.nik.gov.pl/plik/id,103fd70.pdf (in Polish).

19. Wróblewska I, Zborowska I, Dąbek A, et al. Health status, health behaviors, and the ability to perform everyday activities in Poles aged $\geq 65$ years staying in their home environment. Clin Interv Aging 2018; 13: 355-363, doi: http://doi.org/10.2147/CIA.S152456.

20. Derejczyk J. Finansowanie opieki zdrowotnej dla osób w podeszłym wieku - zysk czy zbędne koszty? Kontrola Państwowa 2016; 1 specjalny: 52-74. Available from URL: https://www.nik.gov.pl/plik/id,10370.pdf (in Polish).

21. Susło R, Drobnik J, Mastalerz-Migas A. Systemy zdalnej diagnostyki i monitoringu stanu zdrowia oraz medyczne testy domowe jako środki umacniające podmiotową rolę pacjenta w starzejącym się społeczeństwie. Lek POZ 2017; 3(4): 269-274. Available from URL: https://www.termedia.pl/Czasopismo/-98/pdf-30716-10?filename=systemy.pdf (in Polish).

22. Susło R, Paplicki M, Wróblewska I, et al. Modern technologies serving health safety of old people. In: Jakubaszko J, ed. Postępy medycyny ratunkowej 2018. Wrocław: Polskie Towarzystwo Medycyny Ratunkowej, SR-Poligrafia; 2018: 145-157.

23. Kocowski T, Susło R, Paplicki M. System ratownictwa medycznego a potrzeby zdrowotne starzejqcego się społeczeństwa. In: Jakubaszko J, ed. Postępy medycyny ratunkowej 2018. Wrocław: Polskie Towarzystwo Medycyny Ratunkowej, SR-Poligrafia; 2018; 85-100 (in Polish).

24. Paplicki M. Bezpieczeństwo zdrowotne obywateli w państwowym systemie bezpieczeństwa wewnętrznego. Acta Univ Wratisl Przegl Prawa Admin 2016; 106: 245-257, doi: http://doi.org/10.19195/0137-1134.106.21 (in Polish).

25. Kocowski T, Paplicki M. Organy władzy publicznej, a problem ludzi starszych. In: Fal A, Witczak I, Kuriata-Kościelniak E, eds. Opieka geriatryczna w Polsce. Warszawa: CeDeWu; 2016: 35-53 (in Polish).

26. Goryński P. Sytuacja demograficzno-epidemiologiczna w Polsce i na świecie - nowe wyzwania i perspektywy zmian. Kontrola Państwowa 2016; 1 specjalny: 15-29. Available from URL: https://www.nik.gov.pl/plik/id,10370.pdf (in Polish).

27. Grodzicki T. Kadry i system opieki medycznej dla osób w podeszłym wieku - współpraca różnych sektorów - konieczne zmiany. Kontrola Państwowa 2016; 1 specjalny: 75-85. Available from URL: https://www.nik.gov.pl/plik/id,10370.pdf (in Polish).

28. Drobnik J, Susło R, Kurpas D, et al. Analiza systemu opieki nad osobami starszymi i ich potrzeb zdrowotnych na Dolnym Śląsku. Fam Med Prim Care Rev 2010; 12(2): 165-167 (in Polish).

29. Kollbek P, Lenkiewicz L, Drobnik J, et al. Analiza sposobu podziału środków Narodowego Funduszu Zdrowia i jego konsekwencji dla zaopatrzenia medycznego populacji dolnośląskiej. Probl Hig Epidemiol 2007; 88(1); 84-90 (in Polish).

30. Dwornikowska-Dąbrowska M. Źródła finansowania opieki geriatrycznej w Polsce. In: Fal A, Witczak I, Kuriata-Kościelniak E, eds. Opieka geriatryczna w Polsce. Warszawa: Wydawnictwo CeDeWu; 2016: 82-96 (in Polish).

31. Drobnik J, Susło R, Steciwko A, et al. Instrumenty zabezpieczenia społecznego osób z chorobami otępiennymi na terenie Dolnego Śląska. Fam Med Prim Care Rev 2010; 12(1); 15-18 (in Polish).

32. Dziwisz S. System szczepień ochronnych dzieci - szczepienia jako profilaktyka chorób zakaźnych. Kontrola Państwowa 2016; 6: 91-98. Available from URL: https://www.nik.gov.pl/plik/id,12711.pdf (in Polish).

33. Hak E, Opstelten W, Looijmans-van den Akker I, et al. Influenza vaccination in the elderly: effectiveness not in doubt. Ned Tijdschr Geneeskd 2008; 152(19): 1081-1083.

34. Paszkiewicz D, Piotrkowski J. Profilaktyka w systemie ochrony zdrowia - walka z nowotworami i chorobami układu krążenia. Kontrola Państwowa 2017; 4: 77-96 Available from URL: https://www.nik.gov.pl/plik/id,15006.pdf (in Polish).

35. Celińska J. Pomoc osobom dotkniętym przemocą domową - specjalistyczne poradnictwo i schronienie dla ofiar. Kontrola Państwowa 2017; 1: 61-75. Available from URL: https://www.nik.gov.pl/plik/id,13010.pdf (in Polish).

36. Drobnik J, Czaprowska I, Susło R, et al. Miejsce i rola praktyki lekarza rodzinnego i medycyny rodzinnej w systemie opieki zdrowotnej. Fam Med Prim Care Rev 2010; 12(2); 159-164 (in Polish).

37. Wasilewski P, Łuczak J. Stan kadry medycznej w Polsce - kto nas będzie leczył w przyszłości? Kontrola Państwowa 2016 ; 5: 63-77. Available from URL: https://www.nik.gov.pl/plik/id,12481.pdf (in Polish).

38. Drobnik J, Czaprowska I, Susło R, et al. Ewolucja szkolenia specjalistycznego w zakresie medycyny rodzinnej w latach 1999-2009. Fam Med Prim Care Rev 2010; 12(3): 622-638 (in Polish).

39. Santana S, Redondo P. Process mapping: a tool to foster intra- and inter-organizational coordination in primary care. Fam Med Prim Care Rev 2018; 20(1): 41-46, doi: http://doi.org/10.5114/fmpcr.2017.72150.

Tables: 0

Figures: 0

References: 39

Received: 12.08 .2018

Reviewed: 14.08 .2018

Accepted: 25.08.2018
Address for correspondence:

Robert Susło, MD, PhD

Zakład Gerontologii

Katedra Zdrowia Publicznego UM

ul. Bartla 5

51-618 Wrocław

Polska

Tel.: +48 71 347-90-29

E-mail: robertsuslo@gmail.com 